
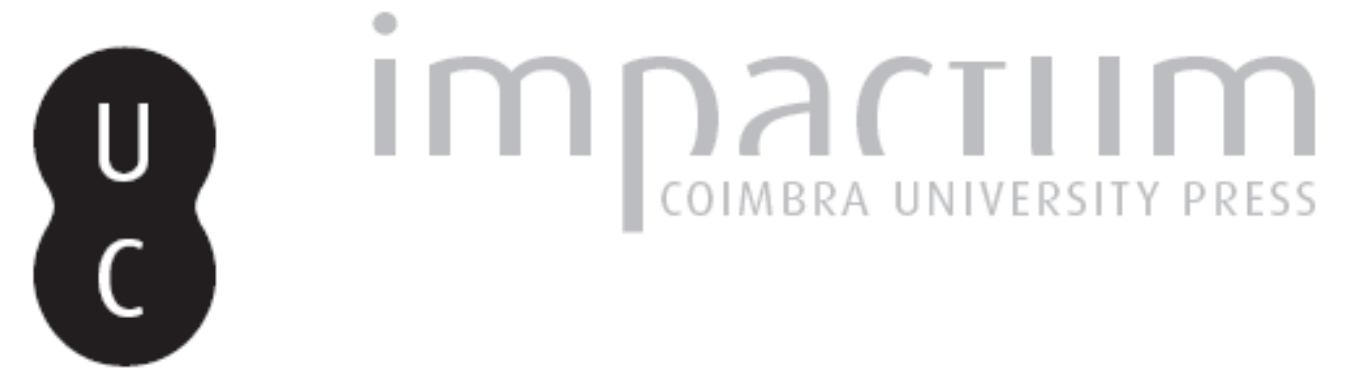

\title{
O pensamento de João de Andrade Corvo e a construção europeia (1870)
}

\section{Autor(es): $\quad$ Silva, Júlio Joaquim da}
Publicado por: Centro de Informação Europe Direct de Aveiro; Centro de Estudos Interdisciplinares do Século XX

URL persistente:

URI:http://hdl.handle.net/10316.2/33981

DOI:

DOI:http://dx.doi.org/10.14195/1647-6336_11_10

Accessed : $\quad$ 26-Apr-2023 09:20:57

A navegação consulta e descarregamento dos títulos inseridos nas Bibliotecas Digitais UC Digitalis, UC Pombalina e UC Impactum, pressupõem a aceitação plena e sem reservas dos Termos e Condições de Uso destas Bibliotecas Digitais, disponíveis em https://digitalis.uc.pt/pt-pt/termos.

Conforme exposto nos referidos Termos e Condições de Uso, o descarregamento de títulos de acesso restrito requer uma licença válida de autorização devendo o utilizador aceder ao(s) documento(s) a partir de um endereço de IP da instituição detentora da supramencionada licença.

Ao utilizador é apenas permitido o descarregamento para uso pessoal, pelo que o emprego do(s) título(s) descarregado(s) para outro fim, designadamente comercial, carece de autorização do respetivo autor ou editor da obra.

Na medida em que todas as obras da UC Digitalis se encontram protegidas pelo Código do Direito de Autor e Direitos Conexos e demais legislação aplicável, toda a cópia, parcial ou total, deste documento, nos casos em que é legalmente admitida, deverá conter ou fazer-se acompanhar por este aviso.

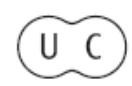


DEBATER

A EUROPA

jul-dez 2014

QUE EUROPA(S)?

CONTEXTOS E DESAFIOS 


\title{
O pensamento de João de Andrade Corvo e a construção europeia (1870)
}

Júlio Joaquim da Silva Professor Associado do Departamento de Filosofia da FCSH-UNL E-mail: juliorodsilva@gmail.com

\section{Resumo}

João de Andrade Corvo (1824-1890) foi um dos políticos portugueses mais lúcidos e originais do nosso século XIX. Entre as suas várias obras e trabalhos destaca-se o livro "Perigos. Portugal na Europa e no Mundo" de 1870, onde analisa o posicionamento internacional do país face a uma Europa em crise. As suas reflexões realizadas num contexto, totalmente diferente do presente, têm a capacidade de nos obrigar a repensar a construção europeia com as suas numerosas ambiguidades e contradições. Reler e repensar Andrade Corvo pode ajudar-nos a encontrar caminhos para sair dos múltiplos impasses que afectam a construção europeia.

Palavras-chave: Nacionalidade; soberania; povo; Europa; raça

\begin{abstract}
:
John Andrade Corvo (1824-1890) was one of the most lucid and original Portuguese politicians of our nineteenth century. Among his many works and papers highlight the book "Dangers. Portugal in Europe and in the World" 1870, which analyzes the international position of the country, faces a Europe in crisis. Heir reflections made in a context totally different from the present, have the ability to force us to rethink the European integration with its many ambiguities and contradictions. Reread and rethink Andrade Corvo can help us find ways out of the multiple impasses affecting European construction.
\end{abstract}

Keywords: Nationality; sovereignty; people; Europe; race 


\section{O pensamento de João de Andrade Corvo e a construção europeia (1870) 1 - 1870. Uma encruzilhada da História}

O ano de 2014 na Europa tem sido rico em vicissitudes, afectando decisivamente a sua unidade e consistência e dificultando o processo de construção da União Europeia. As sequelas da crise financeira de 2008 não se esbateram, até agora, mantendo uma perigosa cisão entre os países do norte, mais desenvolvidos e relativamente imunes aos seus efeitos e os países do sul, onde os problemas económicos, suscitados pelas respectivas dívidas soberanas ainda não desapareceram. A revolução na Ucrânia, de 2014, deu lugar à anexação pela Rússia da Crimeia e ao risco de um guerra civil entre pró-ocidentais e russófonos. A crise política internacional, daí derivada, levanta de novo a questão, nunca definida, dos seus limites orientais e, por ricochete a definição da sua identidade específica. Nesta ambiência as divisões, as hesitações e contradições internas, têm um grande peso nas actuais opções da União Europeia e na busca de soluções para os problemas existentes. As reflexões sobre a realidade presente podem obter um contributo positivo das observações dos acontecimentos do passado, nomeadamente dos eventos dramáticos de 1870. Crise, essencialmente política, caracterizada pela reconstrução do mapa político europeu sobre o impacto dos processos de unificação italiano e alemão. O redesenhar da Europa não deixou de chamar a atenção de João de Andrade Corvo (1824-1890) um dos políticos portugueses mais lúcidos e originais do nosso século XIX. As suas observações sobre esta situação dramática foram sistematizadas no livro "Perigos. Portugal na Europa e no Mundo" de 1870 , onde analisa o posicionamento internacional do país face a uma Europa em crise ${ }^{1}$

O autor tem plena consciência da grande transformação pela qual a Europa passa e a profunda ruptura, ou desintegração do sistema político internacional existente ${ }^{2}$. João de Andrade Corvo considera que a diplomacia e a política externa de cada nação assenta num direito público internacional saído do Congresso de Viena de 1815. A situação não seria perfeita, mas preservava uma ordem internacional, com normas e regras bem estabelecidas e, principalmente, conservava o equilíbrio e a paz entre os diferentes estados ${ }^{3}$. A subversão da ordem política internacional pelas grandes nações

\footnotetext{
${ }^{1}$ Cf. Corvo, João de Andrade, Perigos. Portugal na Europa e no Mundo, Porto, Fronteira do Caos, 2005.

${ }^{2}$ Cf. Corvo, João de Andrade, ob.cit., p.17.

3 “ (...) Os tratados de Viena deram proximamente durante meio século a paz à Europa. Os tratados feitos nestes últimos anos não têm tido nem consistência nem duração. - Terrível sintoma!
} 
deu origem a uma situação onde o despotismo e a anarquia reinam e os grandes valores da humanidade são postos em causa: moral, razão, progresso, civilização e paz ${ }^{4}$. A lei do mais forte e a ambição dominam a acção das potências mais poderosas, dando origem ao mundo no "estado de guerra", recriando um realidade marcada pela selvajaria e retrocedendo da civilização para a barbárie. A crítica a uma visão maquiavélica das relações políticas entre os estados é o eixo essencial das suas reflexões, procurando ao mesmo tempo definir possíveis alternativas ${ }^{5}$. Contudo, as ilusões e a ambição das grandes nações é um perigo enorme para as pequenas nações até aí protegidas pelo sistema político internacional pré-existente e o respectivo direito público internacional. 6.

Nesta perspectiva, o perigo para Portugal é enorme pois, neste mundo dominado pela força, o país não está imune às ambições das potências mais poderosas. Assim sendo, importa alertar o povo português para as ameaças que enfrentam com o objectivo de provocar um sobressalto patriótico salvífico da independência nacional:

"Veja a nação, à luz da verdade, os perigos da sua actual situação; analise as causas da angústia em que vive, meça sem pavor a grandeza do abismo em que os erros a podem precipitar: e, se a Providência de todo não abandonou Portugal, que tanto fez outrora para engrandecer a humanidade e alargar os domínios da civilização, o povo saberá salvar-se pela sua energia, pela sua cordura, pelo seu ardor patriótico, pelo seu amor à liberdade, pelo seu apego à moral, à justiça e ao direito.” 7 .

Apesar das justas críticas que se lhes faziam, apesar de haverem sido sofismados e mesmo violados por muitas vezes, os tratados de Viena eram considerados como reguladores na Europa, até que a França se declarou abertamente contra eles. Mantidos pela Inglaterra - que via neles o meio de conservar no continente um equilíbrio essencialmente mecânico, que neutralizava as forças dos principais Estados, conservando a paz ainda que no meio das desconfianças recíprocas desses Estados -, os actos do congresso de Viena não eram, nem o podiam ser, simpáticos à França. Contudo, o pacto de 1815 constituía o direito internacional da Europa. Era perigoso rompê-lo. Todos hesitavam. A França ousou proclamar a destruição da obra, já pouco firme, já em ruínas, que a diplomacia criara em Viena.

Foi prudente o acto da França? É simples a resposta, porque os factos a deram. - A batalha da Sadowa rasgou a última página daqueles tratados, contra os quais a França protestara com a sua voz e com os seus actos em nome do que ela chamava o novo direito.", Corvo, João de Andrade, ob. cit., p.30.

${ }^{4}$ Cf. Corvo, João de Andrade, ob. cit., p.17.

5 “Tudo é contingente. A força e a astúcia dominam. Cala-se a justiça, emudece a moral e o direito diante da ambição e da ousadia. Inventam-se os princípios para servirem em cada caso, e abandonam-se depois se conseguirem os fins. O estado de guerra, em toda a plenitude brutal da selvajaria, é o estado actual das nações que se jactam de civilizadas.”, Corvo, João de Andrade, ob. cit., p.22.

6 “As grandes nações dizem esses factos ser a ambição - essa ambição, que faz esquecer os grandes princípios da moral e da justiça, não respeita o direito e recusa buscar na consciência da humanidade as regras da sua conduta -, uma ambição cega e torpe, uma desonra e nada mais. Onde se esperam glórias aí se encontra a ruína e a desolação: e, se por vezes a fortuna enganosa dá curtas dias de vitória aos que ofendem as leis eternas da moral, esses dias se pagam com dolorosos desenganos e humilhantes derrotas. Às nações pequenas ensinam-lhes esses factos que devem, antes de tudo, contar com a sua própria energia e estar prontas para o combate; disso depende a sua existência. Nas relações recíprocas dos povos não há nada, infelizmente, que possa tranquilizar as nações pequenas.”, Corvo, João de Andrade, ob. cit., p.21

${ }^{7}$ Cf. Corvo, João de Andrade, ob. cit., p.18. 
No entanto, a busca de soluções para os problemas nacionais exigem necessariamente um confronto com a realidade política e com o momento presente dominado pela guerra franco-prussiana (1870) e o anseio universal pela paz na Europa. ${ }^{8}$

A compaixão pelo destino da França, abatida, suscita sentimentos contraditórios ao autor dividido entre o legado cultural e as responsabilidades históricas do II Império (1852-1870) na destruição da anterior ordem internacional:

"Por largo tempo o governo imperial conspirou contra a paz da Europa, preparando na sombra a ruína dos Estados que podiam tolher os impulsos da sua insaciável e desordenada ambição, ou contribuir com os seus despojos para o engrandecimento da França. Esquecidos os princípios do direito público, ou antes, de propósito confundidos, enredados, perdidos no meio das indefinidas e vagas doutrinas de nacionalidade, de raça, de soberania popular, a Europa foi como que precipitada pelo império francês nesse deplorável sistema de imorais cobiças e violentas arbitrariedades, que ameaçam tudo destruir, e de que a própria França está sendo vítima. Os povos têm responsabilidade pelos actos dos governos a quem confiam os seus destinos; essa responsabilidade é sobretudo grande quando os governos derivam o seu poder do sufrágio popular. A da França pelos actos do império é incontestável: e daí proveio o isolamento em que ela se encontrou no princípio da guerra, e a dificuldade de um acordo entre as potências para lhe acudirem, agora que, abatida e quase agonizante, pede a paz em nome da sua liberdade e independência, em nome da civilização e da humanidade." 9 .

Esta constatação vai conduzi-lo a realizar uma análise minuciosa da diplomacia francesa desde os anos 50 do século XIX, evidenciando as distorções do direito público internacional e os erros da política externa de Napoleão III (1808-1873). Com efeito, a participação na Guerra da Crimeia (1853-1856), na Guerra Franco-Austríaca (1859), a intervenção no processo de unificação italiana (1859-1871), as fragilidades na defesa da insurreição polaca de 1863, a incapacidade de enfrentar a Prússia na crise do Ducados de Schleswig-Holstein (1864), as ambiguidades na Guerra Austro-Prussiana (1866) e a aventura mexicana (1862-1867) abriram caminho para o desastre de $1870{ }^{10}$. Na França subverteu a ordem internacional em nome da defesa das nacionalidades e da soberania popular, mas paradoxalmente abriu caminho para o triunfo do seu pior inimigo: a

\footnotetext{
8 "A guerra exterminadora da Prússia com a França comove, assusta, abala profundamente os povos civilizados. A Europa e a América vêem com horror a França agonizante a pedir a paz, e a Alemanha essa nova Alemanha que saiu armada do turbilhão das batalhas - a negar-lha implacável. O mundo quer a paz, e contudo a guerra continua.

Os dois povos - dilacerados ambos pelas mais cruciantes dores, ambos perdendo pelas largas feridas que neles abriu a guerra o melhor do seu sangue - lutam corpo a corpo: um, turvado já pelo delírio da vitória, querendo com injustificável encarniçamento dilacerar, aniquilar o seu adversário já vencido; o outro, impedido pelo dever, iludido ainda com a recordação de passadas grandezas, buscando com inútil temeridade conservar íntegro o solo da pátria. Abatida e a desmoronar-se, a França não se resigna a expiar numa angústia imensa os erros e os crimes dos dois impérios, erros e crimes que ela não só tolerou mas aplaudiu.", Corvo, João de Andrade, ob.cit., p.162-163.

${ }^{9}$ Cf. Corvo, João de Andrade, ob.cit., p.163-164.

${ }^{10}$ Cf. Corvo, João de Andrade, ob. cit., p.25-60.
} 
Prússia. Na verdade, o implacável chanceler Bismarck não olhando aos meios subverteu os princípios da diplomacia francesa a seu favor, utilizando-os para o exercício pura e simples da força na unificação alemã e na exclusão da Áustria ${ }^{11}$. Nesta perspectiva, Napoleão III cometeu um autêntico suicídio nacional pois, avaliou mal a situação internacional e subestimou o verdadeiro adversário. Todavia, Bismarck não deixa de ser igualmente responsável pelo seu maquiavelismo sem escrúpulos na prossecução dos seus objectivos políticos, enunciando desde o início das suas funções os métodos de acção que escolheu sob o lema: "a ferro e fogo" 12 . O imperialismo prussiano nascido de uma "monarquia militar" dos séculos XVII e XVIII, baseia-se num regime absolutista que nega todas as liberdades e empenha-se na edificação de uma nova Europa dominada por uma Alemanha imperial ${ }^{13}$. Assim sendo, a barbárie militarista reinante na Prússia parece vencer a França, sufocada pelo peso do "despotismo" napoleónico num duelo de gigantes que irá determinar o futuro de boa parte da humanidade. No entanto, as suas reflexões sobre este titânico conflito militar não o impedem de revelar a sua simpatia pela pátria da liberdade e da emancipação dos povos do horror do absolutismo. Os erros

11 (...) A França pela sua influência conseguiu, depois de Sadowa, que no tratado de Praga se inserisse num artigo a condição de serem consultadas as populações, antes da anexação definitiva dos ducados à Prússia. $\mathrm{O}$ artigo $5^{\circ}$ do tratado estipula que o imperador da Áustria cederá todos os seus direitos sobre os ducados - direitos de conquista, o que é mais uma das incoerências e perigosas contradições que confundem o direito internacional -, com a reserva porém de que «as populações do Schleswig setentrional serão entregues à Dinamarca, se, por uma livre votação, exprimirem o voto de lhe ficarem unidas.» - Depois da violência de Sadowa, a França interveio para fazer inserir num tratado o reconhecimento do princípio da soberania popular, como complemento do princípio das nacionalidades! (...) A cláusula era vaga quanto ao modo, quanto ao tempo, vaga até em relação à parte da população dos ducados a que se devia aplicar. O artigo do tratado não se cumpriu. O rei da Prússia foi oficialmente proclamado até à fronteira setentrional dos ducados. O princípio das nacionalidades foi esquecido; o da soberania popular desprezado. (...)", Corvo, João de Andrade, ob. cit., p.46-47.

12 "Seis dias depois de constituído no governo (30 de Setembro de 1862) o conde de Birmarck dizia, numa comissão da câmara (o audacioso ministro entrava então na luta contra o parlamentarismo e contra a liberdade, que tem sido um dos caracteres principais da sua administração) dizia, repetimos - referindose aos perigos da Prússia por causa das suas desfavoráveis fronteiras, aos perigos da Alemanha por causa do que ele chamava a multiplicidade assustadora de «existências catilinárias» -, as seguintes palavras, que eram um verdadeiro programa: «Não é com discursos parlamentares e votos das maiorias, mas sim a ferro e fogo que se resolverão as grandes questões da época!», Corvo, João de Andrade, ob. cit., p.40.

13 “A Prússia, monarquia militar, que reúne em si todos os caracteres das monarquias dos séculos XVII e XVIII, e onde as práticas modernas da política são instrumentos para assegurar a autoridade do rei que se eleva acima de todos e de tudo, e o poder ministro que domina com as ousadias do seu ambicioso pensamento e da sua robustíssima vontade o rei, a Prússia, a Alemanha, e aspira mesmo a dominar a Europa inteira.

A Prússia, onde tudo é trabalhar, por uma política incansável e tenaz, em constituir na Alemanha um vasto império, em remodelar a Europa para criar pontos de apoio para si, ou enfraquecer nações rivais; em manter a incerteza no presente e a desconfiança sobre o futuro.

A Prússia, onde de cada homem se faz um soldado; onde no meio de todas as industriais perfeitíssimas prima a das armas e dos engenhos de matar e destruir; onde o espírito militar domina como nos tempos bárbaros; onde a liberdade completa é impossível, porque acima dela e contra ela está a mais forte, a mais feroz e intransigente das paixões que pode assaltar uma nação, a ambição de dominar.", Corvo, João Andrade, ob. cit., p.19-20. 
cometidos pela demagogia e pelo despotismo não podem ferir a importância civilizacional e cultural da grande nação "latina" 14 .

Contudo, na política internacional europeia existe um actor importante que pode fazer intervir de forma positiva na crise aberta pela guerra franco-prussiana: a Inglaterra. O autor dá-lhe uma especial relevância, apelando a uma intervenção imediata pondo de lado a defesa dos interesses próprios em nome da liberdade, da civilização e do direito ${ }^{15}$. João de Andrade Corvo considera-a uma verdadeira guardiã da liberdade no mundo pela qual tem um respeito ilimitado e uma enorme admiração pela sua actividade económica baseada na inteligência e no trabalho. Exemplo de uma economia e de uma sociedade liberal desenvolvida e industrializada padece, no plano da sua política externa, de um egoísmo e desprezo pelos mais fracos que lhe suscita uma profunda animosidade entre os povos ${ }^{16}$. A Inglaterra não é obrigada a intervir

14 “Uma grande e devastadora guerra pôs frente a frente as duas mais poderosas nações da Europa central: a França e a Prússia.

- A França, que há quase um século acendeu aos olhos deslumbrados da Europa a luz esplêndida da liberdade, e proclamou a emancipação dos povos dominados pelos horrores do absolutismo.

A França, a quem as loucuras da demagogia puderam lançar assustada nos braços do império, que a corrompeu e lhe paralisou a energia, mas onde se não extinguiu, nem a memória de passadas grandezas, nem a aspiração a futuros e gloriosos triunfos em prol da civilização.

A França a quem a falta da liberdade fez quase esquecer os grandes princípios da moderna civilização, mas onde a grande voz da consciência pública não deixará de proclamar o dever e de ensinar o caminho da honra.

A França, a quem do despotismo paralisou a actividade intelectual, amorteceu a inspiração, entorpeceu o vigor moral, mas que não perdeu as suas poderosas faculdades nem há-de abandonar o posto eminente, a que lhe dão direito no mundo civilizado as suas honrosas tradições, a sua grande ilustração, e o lugar que ocupa entre os povos da nobre raça latina.”, Corvo, João de Andrade, ob. cit., p.19.

${ }^{15} \mathrm{E}$, quando é tão grave a situação e tão grande a responsabilidade das nações da Europa, poderá a Inglaterra assistir com indiferença cruel ao desmoronamento da França, da sua aliada na guerra do Oriente, da nação que, em homenagem aos princípios económicos da Inglaterra e em benefício dela, lhe abriu os seus mercados? A grande nação inglesa não pode assistir impassível à luta sanguinária que desola a França e a Alemanha, nem pode ser indiferente aos perigos da civilização, da liberdade, e do direito. Se o fizesse por egoísmo, por um cego amor do ganho, por um receio exagerado e nada nobre das eventualidades de um perigo imediato, a Inglaterra mereceria que a Providência a punisse, tirando-lhe o poder e abatendo-a humilhada diante da força. E a Providência não deixa impunes nem os crimes nem as cobardias, quer dos homens, quer das nações.”, Corvo, João de Andrade, ob. cit., p.202.

16 “A Inglaterra tem desempenhado uma nobre missão: a de ensinar ao mundo que se pode ser grande pela liberdade, que se pode ser poderoso conquistando a Natureza pela inteligência e pelo trabalho. Muitas vezes os povos parecem duvidar, nas horas do perigo e da angústia, da eficácia da liberdade para vencer os obstáculos e conjurar os perigos, mas a Inglaterra, com viva confiança, tem entregue sempre à liberdade os seus destinos, vivido e vencido por ela e só por ela. O respeito às suas instituições políticas; o incansável esforço para elevar o espírito e melhorar a sorte do povo; a tolerância mesmo para as exagerações da palavra e da actividade humana, unida à inabalável autoridade da lei, eis a força da Inglaterra, eis o que deve merecer-lhe a admiração e gratidão do mundo. Senhora dos mares, isolada no meio do oceano, a Inglaterra como que se sente viver fora da Europa e se crê desinteressada nos grandes conflitos que põem essa em perigo. Daí nasce essa política dos governos ingleses, que muitas vezes enche de espanto e causa indignação às nações que vivem na Europa Continental esta vida em comum, solidária no bem e no mal, que é justamente uma das grandezas e um dos perigos do mundo. Grande na sua política nacional; grande pela fecunda acção das suas instituições e pela admirável flexibilidade com que estas se adaptam a todo o processo social ou político; grande pela sua admirável capacidade de colonizar, levando às mais remotas regiões a liberdade e o trabalho; a Inglaterra, contudo, nas suas relações com as potências 
constantemente nos conflitos militares das outras nações pondo em causa a paz e prosperidade do seu povo, mas representando o "espírito de independência e liberdade" na Europa, não pode assistir de forma passiva nem ser indiferente ao triunfo do "domínio da força" e do "princípio brutal de conquista" 17 . A traição aos princípios da escola liberal, assentes na defesa da paz e do direito entre as nações, face às abordagens realistas nas quais predomina a apologia da força, seria um suicídio para a Inglaterra, pois poria no futuro em causa, os seus interesses fundamentais ${ }^{18}$.

O autor não limita a sua análise aos limites do continente europeu, introduzindo com grande perspicácia um novo actor nas relações internacionais, gozando de uma posição estratégia e geográfica fundamental entre o Atlântico e o Pacífico: os E.U.A.. A grande potência da América do Norte, muito próxima civilizacionalmente da Europa, é uma intransigente defensora dos valores da democracia liberal e do republicanismo. Assim sendo, tem um papel crucial a desempenhar na situação política actual, pois aliada à Rússia, relacionando-se bem com a Alemanha e a França, poderia mobilizar as potências neutrais a favor da paz, da justiça, do direito e da liberdade ${ }^{19}$. No outro extremo do mundo a Rússia, não deixa de pesar na evolução política internacional pela sua extensão, mas também pela evolução interna positiva desencadeada pelas reformas de Alexandre II (1818-1881), modernizando radicalmente o império czarista e abrindo as portas de uma gradual liberalização do regime. Assim sendo, esta grande potência pode desempenhar um papel positivo no momento presente, moderando os apetites da

estrangeiras tem por vezes dado prova de um egoísmo, de uma ingratidão, de uma inconstância, de uma falta de respeito sincero à justiça, de um desprezo pelos fracos e de uma complacência para com os fortes, de uma falta, enfim, de generosidade e de grandeza, que lhes não têm granjeado nem o respeito nem a simpatia das nações, e muito menos ainda a confiança que estreita as alianças e as consolida.", Corvo, João de Andrade, ob. cit., p.202-203.

17 "Não pode uma laboriosa nação, que emprega as suas faculdades e a sua actividade na gloriosa tarefa de transformar as condições da indústria e de melhorar pelo trabalho a situação física do povo, estar constantemente a arriscar a sua paz e a prosperidade para acudir às lutas que travam entre si as nações dominadas por paixões violentas, por ódios e por ambições insofridas: mas não pode nem deve também um povo grande, poderoso, que representa na Europa o espírito de independência e de liberdade, deixar estabelecer-se, sem protestar, sem fazer ouvir a sua voz autorizada, o domínio da força e o princípio brutal da conquista. Seria uma ignomínia, uma desonra funestíssima à civilização, que nesta hora calamitosa se não ouvisse, proclamando a paz como uma necessidade social e um dever de moralidade, o povo livre de Inglaterra.”, Corvo, João de Andrade, ob. cit., p.203-204

18 "Os grandes interesses ingleses - supondo que só aos interesses materiais deve atender uma grande nação, o que é um erro -, esses interesses imensos de que depende a prosperidade e a grandeza da GrãBretanha, precisam de que no mundo se não estabeleça, feroz e insaciável, o domínio da força. As longínquas colónias de Inglaterra não poderão estar seguras sem que o direito seja respeitado; e a Inglaterra, a não cumprir a missão que lhe incumbe hoje de representar o direito nos conselhos da Europa, mal pode confiar no futuro, apesar mesmo das suas esquadras. Os propugnadores dos princípios da escola que proclama «a paz por todo o preço» decerto não poderão querer a paz à custa do poder e da honra da Inglaterra; antes a quererão arriscando mesmo um conflito para a alcançar.", Corvo, João de Andrade, ob. cit, p.204.

${ }^{19}$ Cf. Corvo, João de Andrade, ob.cit, p.205-207 
Alemanha. No entanto, a persistência da Questão do Oriente e os ressentimentos produzidos pela sua derrota na Guerra da Crimeia (1853-1856), põem em risco a paz no Leste europeu. Esse risco de um novo conflito armado, pode ser evitado se for feita a revisão do Tratado de Paz de 1856, abrindo os Dardanelos à navegação russa e acabando com o encerramento da sua frota no Mar Negro ${ }^{20}$. Assim, o contributo do Império do Czar para a paz na Europa podia ser vital dando os seguintes passos:

"Promover a paz; provocar um congresso; criar adesão nos diferentes Estados que hão-de concorrer a esse congresso; salvar a França; deixar à Alemanha, dentro dos seus naturais limites, a mais ampla liberdade de acção para se constituir; manter a sua aliança com a Áustria; não negar, antes manifestar abertamente, o seu assentimento aos grandes princípios que devem no futuro regular as relações internacionais, e, por essa forma, assegurar a independência dos pequenos Estados, cuja existência é indispensável para manter o equilíbrio moral da Europa e como que amortecer os rudes choques das grandes potências militares." ${ }^{21}$.

\section{2 - As concepções da política internacional}

No entanto, João de Andrade Corvo não considera possível sem uma análise das principais concepções das relações internacionais, encontrar soluções para os problemas políticos colocados à Europa pela Guerra Franco-Prussiana (1870) ${ }^{22}$. De um lado, alinham as doutrinas da soberania popular e do princípio das nacionalidades, estreitamente interligadas, do outro temos as teorias das raças dando origem ao pangermanismo e ao pan-eslavismo. As primeiras serviram de suporte à estratégia diplomática da França e parcialmente à Alemanha nas décadas de 50, 60 e 70, as segundas no mesmo período de tempo serviram de base ao imperialismo alemão e parcialmente do russo. O ponto de partida destas suas reflexões consiste num estudo do princípio das nacionalidades e da soberania nacional, centrando-se na ideia de nação nas suas diferentes acepções, ${ }^{23}$ equaciona os diversos elementos constitutivos de uma identidade nacional, recusando sucessivamente: a unidade da língua, a comunidade de raça e os acidentes geográficos. O primeiro é recusado pelos factos que demonstram a existência de nações com a mesma língua como Portugal e o Brasil, a Inglaterra e os Estados Unidos, ou com múltiplas línguas como a Suíça. O segundo é refutado por ser muito raro o caso de nações em que não se encontrem raças muito diferentes e o terceiro

\footnotetext{
${ }^{20}$ Cf. Corvo, João de Andrade, ob. cit, p.190-194

${ }^{21}$ Cf. Corvo, João de Andrade, ob. cit, p.194-195

${ }^{22}$ Cf. Bond, Brian, War and Society in Europe. 1870-1890, Guernsey, Sutton Publishing 1988, p.13-39.

${ }^{23}$ Cf. Corvo, João de Andrade, ob. cit, p.31-32
} 
pela irrelevância das chamadas fronteiras nas economias modernas desenvolvidas e industrializadas. Na verdade, são formulações teoricamente inválidas que só são úteis para justificar os processos de expansão e de anexação de territórios, ou países, por parte das grandes potências ${ }^{24}$.

O conceito de nação de João de Andrade Corvo é bastante diferente estruturando-se na noção do consenso político generalizado num determinado território, aos quais adicionam as tradições e costumes. Definição antecipando certos aspectos das concepções posteriores de Ernest Renan (1823-1892) mas, situando-se decisivamente no universo de um patriotismo, ou nacionalismo, não xenófobo de orientação liberal:

“Uma reunião de homens agrupados sobre um certo território, constituindo, pelo assentimento geral, uma entidade política, com unidade de governo, no que respeita à manifestação e defesa dos interesses comuns eis o que constitui uma nação. A unidade de poder político representando e dirigindo os comuns interesses perante os estrangeiros, é uma condição essencial da existência de uma nação. O assentimento dos povos é a outra condição igual essencial. As tradições, os laços, por assim dizer, de família entre os habitantes de um dado território; as analogias de carácter e de costumes; as repugnâncias ou incompatibilidades mais ou menos profundas, resultantes dos elementos constitutivos da sociedade ou das leis, entre um povo e os seus vizinhos, são circunstâncias que mantêm a separação das nações, que contribuem poderosamente para afirmar a sua autonomia e para assegurar os seus direitos à independência." 25 .

Seja como for, a dificuldade em definir com grande precisão a noção de nação, destrói completamente a credibilidade do princípio das nacionalidades, como base de um novo direito público internacional. A aplicação à prática política serve apenas para justificar as ambições das grandes potências, tendo sido largamente utilizado pelo Segundo Império francês para violar os antigos tratados que escoravam o equilíbrio político europeu. O conceito de soberania popular, ou nacional, serviu para complementar os processos arbitrários da diplomacia gaulesa de Napoleão III (18081873), confirmando os factos consumados com o aparente, mas não verdadeiro consentimento dos povos, através do processo do sufrágio universal considerado, pelo autor, imaturo $^{26}$. Todavia, o princípio das nacionalidades e a soberania nacional criam problemas adicionais no plano das relações internacionais, nada fáceis de resolver, uma

\footnotetext{
${ }^{24}$ Cf. Corvo, João de Andrade, ob. cit, p.31-33

${ }^{25}$ Cf. Corvo, João de Andrade, ob. cit, p.33-34. Sobre as concepções liberais das Relações Internacionais consultar: Dunne, Tim, "Liberalism", The Globalization of World Politics. An introduction to international relations, edited by Baylis, John \& Smith, Steve, Oxford, University Press, 2001, $2^{\text {nd }}$ edition, p.162-181.

${ }^{26}$ Cf. Corvo, João de Andrade, ob. cit, p.33-34.
} 
vez que colocam, na origem do desmembramento das nacionalidades existentes, o direito das nações disporem de si:

"Ninguém põe em dúvida hoje o direito que tem o indivíduo de dispor livremente de si, de regular por si os seus interesses e as suas relações com os outros indivíduos. Não deve este mesmo direito estender-se às famílias, às tribos, às nações? E, reconhecendo-se às nações o direito de disporem de si, não é claro que esse direito deve existir tanto para as nações pequenas se unirem às grandes, como para se desunirem as diversas partes de um reino, de uma província, de uma cidade? Quem aceitaria, sem temer pela civilização, este princípio em todas as suas consequências? Não seria ele a origem do desmembramento das nacionalidades, ainda as mais bem constituídas, e da destruição das grandes forças morais, das grandes forças produtivas da sociedade moderna? Não poderiam em tal caso as minorias inteligentes, nobres e patrióticas, ser sacrificadas pela estupidez, pela cobardia ou pela imoralidade de maiorias conquistadas pela corrupção ou pela força? Não é fácil ver, já pelos exemplos, já pela reflexão, que o princípio da soberania nacional, hipocritamente invocado, por enquanto só tem servido e só pode servir para os fortes disporem dos fracos, obrigando estes a aceitar por um acto solene as leis que a violência lhes quer impor? Tomar posse de um povo pela força, ou pela astúcia, ou por um tratado mais ou menos imoral; submetê-lo depois à pesada acção da autoridade; corrompê-lo ou seduzi-lo por mentidas promessas; e, finalmente, chamá-lo a votar a sua própria aniquilação como entidade política, é engenhoso e profícuo. O mais que importa, a quem só cuida dos fins sem se preocupar com a imoralidade dos meios?" 27.

A recusa da "imoralidade dos meios" no seu discurso anti-maquiavélico não se restringe à crítica do princípio das nacionalidades e da soberania nacional, mas aplica-se igualmente a um conceito pertencente ao "velho" direito público internacional: o equilíbrio europeu. Contesta a legitimidade deste velho princípio pela sua transformação num sistema de compensações entre as grandes potências, por se traduzir numa nova forma de violência contra as nações mais fracas, sendo um complemento dos processos nefastos modernos ${ }^{28}$.

Considera ainda mais perigosas as teorizações sobre as raças, pois são mais eficazes na justificação da edificação de grandes impérios do que o princípio das nacionalidades,

\footnotetext{
${ }^{27}$ Cf. Corvo, João de Andrade, ob. cit, p.34-35.

28 "Estes princípios - o das nacionalidades e o da soberania popular - não fizeram esquecer contudo o antigo sistema do equilíbrio europeu. Antes supunha-se conveniente manter o que estava estabelecido pelos tratados, conservando cada nação dentro dos limites que lhes haviam sido assinados pelos factos e pelas convenções. Assim se buscava conservar o equilíbrio europeu: coisa sempre variável, apesar de tudo, como o provam os factos. Esse sistema, puramente fantasia - porque é instável o equilíbrio, e não é possível fixar uma disposição de forças que o mantenha estável -, esse sistema ainda é tido em conta, não para conservar a paz senão para autorizar o que se chama compensações. Uma grande potência comete um roubo ao norte da Europa? Esse facto, segundo o sistema imoralíssimo das compensações, autoriza outra grande potência a cometer também um roubo ao sul da Europa para manter o equilíbrio. Os fracos dão a matéria-prima dessas compensações; sem que se busque saber, a não ser depois do facto e como mera formalidade, o que eles pensam de tão cruéis e brutais atentados.", Corvo, João de Andrade, ob. cit., p.31-32.
} 
ou a soberania popular ${ }^{29}$. Daí o perigo ser maior ao abrirem caminho às perversões do pangermanismo e pan-eslavismo nas relações internacionais:

“Em 1862, um diplomata russo publicou uma obra singular, intitulada: Os gabinetes e as alianças da Europa. Para este escritor, que representava até certo ponto as ideias de uma escola de publicistas do norte, o futuro pertence aos grandes complexos de Estados. Estes complexos de Estados resumem-se em três raças - a latina, a germânica e a eslava - às quais correspondem três centros de gravitação: a França, a Prússia e a Rússia. O pan-eslavismo, o pangermanismo, o panlatinismo são nomes que representam nas escolas da Alemanha as teorias do diplomata russo. Essas teorias não deixam de ter influência nos destinos da Europa, apesar de absurdas, apesar de contrárias à verdade antropológica e à história." 30 .

O pangermanismo é sem dúvida o problema mais importante, do ponto de vista da crise internacional, criada pelo choque de dois imperialismos: o francês e o prussiano. $\mathrm{O}$ espírito alemão e especialmente o prussiano parecem ser propensos ao desenvolvimento de um nacionalismo alemão obcessivamente centrado no sonho imperial de uma "unidade germânica" baseada na "identidade da raça". A ambiência cultural da Alemanha também favorece esta tendência, pois existem intelectuais alemães, como o escritor Varnhagen von Ense e o historiador Gervinus, que defendem estas ideias, atrevendo-se mesmo o último a afirmar a superioridade germânica e a decadência inevitável das "nações latinas". O momento presente da história mundial pertenceria à "raça germânica", justificando a edificação da "grande pátria alemã", a submissão da Europa a uma Alemanha imperial cujo centro seria a Prússia ${ }^{31}$. As vitórias da Prússia são um perigo constante, transformam a Alemanha num vasto império, dando forma à teoria das raças e tornando-se numa grande ameaça às nações identificadas como pretensa "raça latina". Porém, a esperança de travar este processo não se desvaneceu e assenta em factores internos da própria Alemanha: "o grande e elevado espírito alemão" e a "profunda fermentação democrática". Aliás, é bem possível que a Alemanha acabe, também ela, vítima da sua própria ambição num desastre semelhante, ou pior, do que o francês, ficando reduzida a um conjunto de ruínas ${ }^{32}$.

Todavia, a própria dinâmica induzida pelo pangermanismo produz anticorpos da mesma natureza, sendo o pan-eslavismo russo o caso mais relevante:

\footnotetext{
29 “Hoje, as coisas são diferentes. Já há teorias para servirem de fundamento à constituição dos grandes impérios; já há fórmulas para pôr em execução os planos de conquista. A teoria das nacionalidades - não das nacionalidades que existem, mas das nacionalidades que cria a fantasia - tem já sido posta em prática. Como esta, contudo, não era suficiente para se chegar à formação de impérios colossais, tratou-se de desenvolver a teoria das raças, pela qual se deve dividir a Europa em três grandes impérios: o império eslavo, o império germânico e o império latino. Este último, se conseguisse formar-se, seria, segundo os planeadores do norte, condenado à degradação.”, Cf. Corvo, João de Andrade, ob. cit, p.169.

${ }^{30}$ Cf. Corvo, João de Andrade, ob. cit, p.31-32.

${ }^{31}$ Cf. Corvo, João de Andrade, ob. cit, p. 167-169.

${ }^{32}$ Cf. Corvo, João de Andrade, ob. cit., p.172-173
} 
“Um grande império, criado pelas vitórias, apoiado na força e originado pelo princípio das afinidades da raça, não pode deixar de excitar as apreensões, de irritar as susceptibilidades, e de aceitar as apreensões, de irritar as susceptibilidades, e de acender as paixões em toda a Europa. As vitórias do pangermanismo levam directamente à agitação armada do pan-eslavismo, e, mais ou menos rapidamente, à guerra. Em face da Alemanha, unificada pelo militarismo, levantar-se-á a Rússia com todo o seu poder e todas as suas aspirações. - Embora hoje exista a paz, amanhã chegará a guerra. É uma destas tendências fatais a que a vontade dos homens não pode resistir." ${ }^{33}$.

No entanto, a situação torna-se mais complexa, pois à propaganda do pan-eslavismo entre as populações eslavas, incentivando "o espírito de raça", interliga-se estreitamente com a afirmação da "religião cristã grega" e o sonho da "constituição de um grande império do Oriente" em detrimento da Turquia ${ }^{34}$. A Questão do Oriente pode reacenderse e dar lugar a uma "guerra geral" na Europa resultante do esforço de compensar as perdas resultantes da derrota na Guerra da Crimeia com uma expansão no ExtremoOriente e, presentemente, com a tentação de renovar a luta com a Turquia para constituir "o grande império eslavo" 35 . O pior cenário consistiria numa aliança contranatura da Prússia e da Rússia para a constituição simultânea de um império germânico e de um império eslavo. A Rússia não tem nenhum interesse em reavivar a Questão do Oriente e provocar um conflito generalizado pois, o interesse do império czarista coincide neste momento com o da Europa na preservação da paz. Aliás, “a concentração da raça germânica" num único estado destruiria as barreiras ao expansionismo alemão, aniquilando a Áustria e a França e ameaçando a existência dos "povos de raça latina" e a "paz do mundo" ${ }^{36}$. A aplicação das teorias das raças à política internacional é nefasta, servindo para avalizar a utilização pura e simples da força a favor dos imperialismos nascentes ou das grandes potências existentes ${ }^{37}$. O problema principal consiste contudo na falta de consistência destas concepções assentes na raça, cuja credibilidade levanta múltiplas dúvidas permitindo-lhe falar de uma "fantasia eminentemente perigosa". Efectivamente, a formação das raças ao longo da história desde os tempos pré-históricos atesta a existência de múltiplas transformações e aglomerações de povos com caracteres etnográficos diferentes. Torna-se assim problemática a identificação das suas origens e evolução no tempo e no espaço e ainda mais duvidosa a definição da sua "superioridade relativa" ou da sua "degradação". Estas

\footnotetext{
${ }^{33}$ Cf. Corvo, João de Andrade, ob. cit., p.190

${ }^{34}$ Cf. Corvo, João de Andrade, ob. cit., p.190

${ }^{35}$ Cf. Corvo, João de Andrade, ob. cit., p.191-192

${ }^{36}$ Cf. Corvo, João de Andrade, ob. cit., p.193-194

${ }^{37}$ Cf. Corvo, João de Andrade, ob. cit., p.200-201
} 
reflexões são comprovadas pelo progresso geral da humanidade inerente a todos os grupos étnicos e pelos acontecimentos políticos. A ascensão e a queda da França contradiz o discurso das raças superiores e das raças decadentes, enquanto os Estados Unidos, constituídos pelas ditas "raças distintas" da Europa são o exemplo mais claro do sucesso desta fusão ou convivência positiva dos diversos grupos étnicos. Aliás, a pureza racial de uma nação é muito duvidosa quer do ponto de vista geográfico quer da perspectiva da unidade da raça ${ }^{38}$. João de Andrade Corvo não se cansa de salientar a falsidade das suas pretensões científicas aplicadas aos seres humanos reduzindo-os a uma realidade puramente animal ${ }^{39}$.

\section{3 - A nova Europa e Portugal}

O principal problema, criado pelos múltiplos discursos sobre as raças, resulta das suas consequências futuras para a constituição da Europa, porque permite a organização de grandes estados à custa dos pequenos prejudicando gravemente a liberdade, a civilização, o direito público internacional e a paz do mundo. As afirmações da utilidade da sua formação para impedir o desencadear das guerras entre os povos é uma óbvia falsidade, pois só sufocando os interesses legítimos pela força seria possível evitar a sua violenta expressão. Além disso, os impérios assentes nas "rivalidades reais ou supostas das raças", com fronteiras comuns, seria a receita completa para o desastre através do desencadear de conflitos mortíferos ${ }^{40}$. O perigo para a Europa, da constituição destas entidades supranacionais, é também inerente aos que se reclamam dos princípios das nacionalidades e, muito mais abrangente, nas suas nefastas consequências. A liberdade política, elemento essencial da identidade europeia, será pura e simplesmente erradicada por esforços destes "unificadores", unicamente portadores do despotismo, da guerra, da opressão dos povos e da destruição do direito e da moral social. A própria ideia de cidadania, que é um dos pilares da visão ocidental da política, seria totalmente destruída

\footnotetext{
${ }^{38}$ Cf. Corvo, João de Andrade, ob. cit, p. 169-170.

39 “A doutrina das raças é um imenso perigo, porque quer substituir à longa elaboração social que formou as verdadeiras nacionalidades, o instinto de sangue; à espiritualidade a materialidade; às relações morais as relações tecnológicas; porque quer enfim classificar os povos como se classificam os animais num museu, pelos caracteres histórico-naturais.”, Corvo, João de Andrade, ob.cit., p.209. Sobre esta questão consultar: Hannaford, Ivan, Race. The History of na idea in the West, Washington, D.C. / Baltimore /London, The Woodrod Wilson Center Press / The Johns Hopkins University Press, 1996, p.235-323.

${ }^{40}$ Cf. Corvo, João de Andrade, ob. cit, p. 170-171
} 
e os valores fundamentais da humanidade postos em causa ${ }^{41}$. As consequências para a Europa podiam ser ainda mais gravosas, pondo em causa a diversidade cultural proporcionada pelos múltiplos pequenos estados:

"Se esses grandes impérios se constituíssem, absorvendo todas as pequenas nacionalidades, o espírito da Europa sofreria uma grande depressão moral, porque lhe faltaria a maior das suas maravilhosas qualidades: a unidade de civilização na variedade das compleições, das formas, dos caracteres políticos. Esse grande luzeiro, formado pelas variadas irradiações de muitos centros luminosos, tornar-se-ia em clarão sinistro de incêndio destruidor. Em contacto uns com os outros, e como desacompanhados de toda a influência moderadora, os grandes impérios consumir-se-iam em guerras implacáveis, em guerras de raça; até que a democracia, inspirada pelos grandes sentimentos da humanidade, desmembrasse outra vez esses colossos." ${ }^{42}$.

Além disso, as pequenas nações são fundamentais para a Europa por serem "centros de liberdade e campos neutrais" onde se realiza um processo criativo de elaboração dos "grandes problemas da civilização". Contudo, a neutralidade dos pequenos estados garantida pelas grandes potências, tem outra utilidade, pois podem constituir barreiras entre os maiores estados evitando muitos dos casus belis capazes de provocar conflagrações militares generalizadas no mundo ${ }^{43}$. A paz exige a preservação dos pequenos estados, pois a sua existência é a melhor forma de garantir, através de alianças e pactos mútuos, os interesses políticos, económicos e sociais, comuns à união harmoniosa dos europeus. Isto é algo que os impérios não conseguem fazer a não ser pela força e repressão dos seus cidadãos o que é totalmente contrário ao progresso, pois "civilização progressiva sem liberdade não pode existir" ${ }^{44}$. O papel dos pequenos estados na construção de uma nova ordem europeia não exclui os grandes estados da sua responsabilidade na salvaguarda do direito, da justiça e da liberdade dos povos ${ }^{45}$. Isto explica a concepção do autor da necessidade de cooperação dos estados com "forças desiguais, mas com um desenvolvimento igual" no estabelecimento da "justiça" e da

\footnotetext{
41 "No dia em que se realizassem as esperanças dos unificadores; no dia em que o continente europeu se grupasse em grandes centros políticos, em grandes impérios fundados, já sobre a teoria clássica das nacionalidades, já sobre a não menos elástica e não menos perigosa das raças, a liberdade política teria muito que padecer, teria que passar por uma longa e penosa crise. A história da formação dos grandes Estados da Europa é a história do despotismo, da guerra, da opressão dos povos pela força e dos ataques violentos ao direito e à moral social. A liberdade tende a unir os povos pelas relações de uma desinteressada fraternidade e não pela concentração do poder; não por essa unificação que destrói a actividade e mata a iniciativa dos cidadãos, que nivela todos e tudo para melhor conseguir a união material, a união pela força e pela ilimitada acção da autoridade central.”, Cf. Corvo, João de Andrade, ob. cit, p.200.

${ }^{42}$ Cf. Corvo, João de Andrade, ob. cit, p.200-201

${ }^{43}$ Cf. Corvo, João de Andrade, ob. cit, p.201

${ }^{44}$ Cf. Corvo, João de Andrade, ob. cit, p.172

${ }^{45}$ Cf. Corvo, João de Andrade, ob. cit, p.202
} 
"razão" e na recusa da "violência" e da "força" 46 . Nesta perspectiva, João de Andrade Corvo considera a razão de ser das dificuldades europeias a ausência de um verdadeiro direito público internacional que deve surgir do reconhecimento dos diferentes interesses dos povos ${ }^{47}$.

No entanto, a situação é especialmente difícil por nos encontrarmos confrontados com uma crise política de grandes dimensões que não é um caso isolado na história da Europa, não deixando por tal facto de ser extremamente perigosa, pois pode conduzir a um colapso civilizacional. Apesar destas perspectivas negativas, o autor não assume uma postura totalmente pessimista, deixando em aberto a possibilidade de reverter a evolução destrutiva dos acontecimentos políticos:

"A sociedade humana passa, de séculos em séculos, por crises tremendas, por imensos cataclismos. O espírito das nações, turvado e obscurecido pelas paixões, parece esquecer os puros e grandes princípios que Deus pôs na alma da humanidade, para que lhe servissem de guia e a iluminassem. Convulsões profundas agitam nessas grandes crises as nações; e, onde tudo parecia grandeza, força, prosperidade, onde se mostravam os esplendores de uma elevada civilização, não se vê mais do que desolação, misérias, angústias, e a mais profunda e pavorosa depressão moral. Esses paroxismos são sempre a consequência fatal da corrupção, de paixões cegas e ferozes, de vidas sociais, de ambições torpes, do despotismo dos governos ou da anarquia dos povos. - Estaremos nós numa dessas crises que fazem cair uma civilização e cobrem de ruínas o mundo? Tenhamos esperança no futuro, confiemos na razão e na consciência humana. A Europa está, é verdade, passando por uma grande transformação: mas se o egoísmo e a ambição não levarem as nações a esquecer os seus deveres e a desconhecer os verdadeiros e justos interesses da sociedade, a grande transformação far-se-á em benefício da civilização, da liberdade e da justiça, salvando a Europa do abismo em que neste momento ela parece estar-se precipitando." ${ }^{48}$.

Assim sendo, torna-se urgente encontrar uma saída para a situação presente criada pela guerra franco-prussiana, ameaçando a Europa com um colapso total resultante do uso ilimitado da violência e da força guerreiras, bárbaras opostas à própria ideia de civilização $^{49}$. A melhor proposta será a convocação de um congresso geral onde

${ }^{46}$ Cf. Corvo, João de Andrade, ob. cit, p.171-172

47 "A falta de sãos princípios de direito internacional é a causa principal dos sofrimentos da Europa. A multiplicidade de interesses legítimos, manifestando-se livremente no grande congresso intelectual que a imprensa e a tribuna têm sempre aberto na Europa, deve necessariamente levar à criação de um direito que regule as relações dos povos.", Corvo, João de Andrade, ob. cit, p.171

${ }^{48}$ Cf. Corvo, João de Andrade, ob. cit, p.208.

49 "A guerra da Alemanha e da França é um imenso perigo para a Europa. Quando às armas se confia a sorte dos Estados e o futuro dos povos, a razão humana perturba-se, e falta às nações, como aos homens, serenidade de ânimo para dominarem os ímpetos do orgulho ou as sugestões da ambição. A paz é necessária, para que a força não ouse tudo e não queira decidir, cega e brutal, todas as questões, tanto da política internacional, como da política interna das nações. É urgente que a razão dos povos se faça ouvir, para que a violência não destrua o que tem direito de existir, para que o acaso não decida nos campos de batalha da existência das nações e dos destinos da civilização.", Corvo, João de Andrade, ob. cit, p.208209. 
estarão representados os interesses de todas as nações capaz de resolver os problemas políticos internacionais e trazer a paz, a prosperidade e grandeza à Europa ${ }^{50}$. As resoluções a tomar pelo congresso devem ser várias, começando por uma garantia colectiva da conservação da independência e da neutralidade das pequenas nações, incluindo "a completa independência do papa". Deve estabelecer-se também para evitar ou pelo menos retardar o desencadear das hostilidades, o "estado de guerra", a obrigatoriedade prévia de uma "mediação pacificadora" e a constituição de uma "liga permanente" que permita assegurar a sua realização. Finalmente, o congresso deve inspirar-se em "elevados princípios" e dotar-se de poderes que lhe permitam sanar ou minorar as consequências dos conflitos presentes e prevenir os conflitos futuros ${ }^{51}$. Nesta perspectiva, a necessidade de afastar de uma vez por todas o flagelo da guerra exige uma "santa aliança" dos povos capaz de impor uma mediação pacífica prévia a todas as nações:

“A guerra, esse horrível flagelo da humanidade, não pode continuar a ser a base da constituição dos Estados e a sua principal preocupação. É, repetimo-lo, necessário que o arbítrio e as paixões dos povos ou dos governos não possam determinar uma crise como aquela por que está passando a Europa. Deixemos tradições selvagens, que são a desonra da humanidade. Que não se dê à força o primeiro lugar, quando se trata dos grandes interesses das nações. Num pacto solene, numa verdadeira santa-aliança dos povos obriguem-se as nações a não fazerem a guerra umas às outras, sem primeiro se sujeitarem nos seus agravos a uma mediação pacificadora." 52 .

Apesar de tudo, o autor não tem grandes ilusões sobre a eficácia destas medidas isoladamente, mas acredita que a publicidade destes processos actuaria sobre a opinião pública internacional estabelecendo uma "barreira moral" capaz de travar efectivamente os ímpetos militares dos governos e dos povos, traduzindo também o triunfo do “espírito moderno dos povos" nos círculos diplomáticos dos decisores políticos ${ }^{53}$.

A realidade desta crise deixa em perigo um pequeno país como Portugal e portanto é necessário fornecer uma solução capaz de garantir a sobrevivência e independência da nação lusa. Numa época marcada pelos problemas criados à independência nacional pela questão da União Ibérica e o iberismo o posicionamento no campo internacional do país é extremamente delicado. A longa e pormenorizada descrição dos acontecimentos dos anos 60 referentes às tentativas espanholas do general Prim de oferecer o trono de Espanha a um monarca português demonstram bem os seus receios face a uma possível

\footnotetext{
${ }^{50}$ Cf. Corvo, João de Andrade, ob. cit, p.210-211

${ }^{51}$ Cf. Corvo, João de Andrade, ob. cit, p.212-213

${ }^{52}$ Cf. Corvo, João de Andrade, ob. cit, p. 213

${ }^{53}$ Cf. Corvo, João de Andrade, ob. cit, p.213-214
} 
anexação por parte do país vizinho ${ }^{54}$. As suas preocupações centram-se na busca de alternativas aos nacionalismos dominantes capazes de proteger Portugal dos perigos externos. O patriotismo é para o autor a solução mais sã pois, não se confunde com o ódio irreflectido e a violência xenófoba dos grandes impérios. O patriotismo é o amor à família nacional, à liberdade, às tradições, a defesa da felicidade e do engrandecimento nacional, mas sem ser à custa da desgraça e do abatimento das outras nações. $\mathrm{O}$ amor da independência não pode ser uma "paixão cega", um "fanatismo" destruidor, mas um elemento de valorização intelectual, de incremento das liberdades e de desenvolvimento da prosperidade de uma nação ${ }^{55}$.

Tendo em consideração estes factos os caminhos de Portugal passam necessariamente por uma presença no "futuro congresso" europeu e consequentemente obter pela "garantia colectiva das nações da Europa, o nosso futuro". Aliás, na sua opinião o país tem uma série de vantagens no campo da política com os quais pode jogar positivamente para obter alianças vantajosas que lhe garantam a independência:

"Com uma população considerável, muito superior a quatro milhões de habitantes; situado no extremo ocidente da Europa; banhado pelo oceano e possuindo um dos primeiros portos do mundo, tendo ilhas admiravelmente dispostas no caminho das duas Américas, do norte e do sul; senhor de vastíssimas colónias na África ocidental e oriental, na Índia, na China e na Oceânia, Portugal pode e deve considerarse um Estado dos mais importantes entre as potências de segunda ordem. Para manter a sua posição, melhorar as suas condições económicas e políticas, e aumentar a sua importância e influência, Portugal, além de bom governo, boa política e boa administração, precisa de boas alianças." 56 .

Assim sendo, importa manter uma activa cooperação económica e intelectual com a vizinha Espanha, baseada na tradicional amizade das duas nações e no pleno respeito pela respectiva independência. A aliança antiga com a Inglaterra deve ser mantida e desenvolvida, apesar das dúvidas sobre a actuação que no passado nem sempre foi correcta derivada da influência das doutrinas da "escola de Manchester". Na verdade, neste país o peso da opinião pública é tão grande que a governa de facto e assim sendo, a nação inglesa honrará os seus antigos compromissos com Portugal. Os Estados Unidos podem igualmente dar um contributo importante para a causa da independência nacional, pois a nossa fronteira atlântica estabelecida pelos Açores fornece a hipótese de tornar o nosso país o "primeiro empório do comércio da América com a Europa”. Assim sendo, uma aliança entre os dois estados, respeitando a neutralidade de Portugal e das

\footnotetext{
${ }^{54}$ Cf. Corvo, João de Andrade, ob. cit, p.67-111

${ }^{55} \mathrm{Cf}$. Corvo, João de Andrade, ob. cit, p.119

${ }^{56}$ Cf. Corvo, João de Andrade, ob. cit, p.216-217
} 
suas possessões, será muito vantajoso para os dois povos ${ }^{57}$. Nesta perspectiva, o futuro de Portugal passa necessariamente pela pertença a uma Europa renascida através de um congresso geral que estabeleça um novo direito público internacional assente na paz, na cooperação e defesa da liberdade, de todos os participantes e da negação absoluta da violência e da força acabando definitivamente com um mundo dominado pelo "estado de guerra".

${ }^{57}$ Cf. Corvo, João de Andrade, ob. cit, p.218-219 